\title{
Intake, milk production, ruminal, and feed efficiency responses to dietary cation-anion difference by lactating dairy cows
}

\author{
M. E. Iwaniuk and R. A. Erdman ${ }^{1}$ \\ Animal and Avian Sciences Department, University of Maryland, College Park 20742
}

\begin{abstract}
Previous meta-analyses of the effects of dietary cation anion difference (DCAD; $\mathrm{mEq} / \mathrm{kg} ; \mathrm{Na}+\mathrm{K}-\mathrm{Cl}$ - S) in lactating dairy cow diets used studies conducted after the development of the DCAD concept. Dietary buffers, such as $\mathrm{NaHCO}_{3}$ and $\mathrm{K}_{2} \mathrm{CO}_{3}$, increase DCAD and have been used in lactating dairy cow diets for several decades. However, most published studies on buffer feeding were conducted before the development of the DCAD concept. Our objective was to determine the intake, milk production, ruminal, and feed efficiency responses to DCAD using previous studies with dietary buffer addition and more recent studies that focused on DCAD as dietary treatments. The database consisted of 43 articles that were published between 1965 and 2011. The studies included 196 dietary treatments and 89 treatment comparisons with a range in DCAD from -68 to $811 \mathrm{mEq} / \mathrm{kg}$ of diet DM, with the vast majority between 0 and $500 \mathrm{mEq} / \mathrm{kg}$ of diet DM. For studies that lacked analyses of one or more of the dietary strong ions $(\mathrm{Na}, \mathrm{K}, \mathrm{Cl}$, or $\mathrm{S})$, ion percentages were estimated from ingredient composition using the 2001 dairy National Research Council software. Two basic models were used to evaluate DCAD responses using the NLMIXED procedure in SAS 9.2 (SAS Institute Inc., Cary, NC): (1) a simple linear model, $\mathrm{Y}=\mathrm{A}+\mathrm{B} \times(\mathrm{DCAD})$, where $\mathrm{A}=$ intercept and $\mathrm{B}=$ the increment (slope) in performance per unit DCAD $(\mathrm{mEq} / \mathrm{kg}$ of diet DM); and (2) a nonlinear model, $\mathrm{Y}=\mathrm{A}+\mathrm{M}\left[1-\mathrm{e}^{(\mathrm{K} \times \mathrm{DCAD})}\right]$, where $\mathrm{M}=$ maximal increment in performance from DCAD and $\mathrm{K}=$ the rate constant. In both models, study was designated as the random effect. The DCAD effects best described by the linear model included milk fat percent, fat yield, ruminal $\mathrm{pH}$, NDF digestibility, and feed efficiency $[3.5 \%$ fat-corrected milk (FCM; $\mathrm{kg}) /$ dry matter intake (DMI; kg)] where a $100 \mathrm{mEq} /$ $\mathrm{kg}$ increase in DCAD resulted in respective increases of $0.10 \%, 36 \mathrm{~g} / \mathrm{d}, 0.032 \mathrm{pH}$ units, $1.5 \%$ NDF digestibility,
\end{abstract}

Received June 11, 2015.

Accepted July 8, 2015.

${ }^{1}$ Corresponding author: erdman@umd.edu and $0.013 \mathrm{FCM} / \mathrm{DMI}$ units. The DMI, milk yield, and $3.5 \%$ FCM were best described by the nonlinear model where the maximal responses were 1.92, 1.11, and 4.82 $\mathrm{kg} / \mathrm{d}$, respectively. The expected increments in DMI, milk production, and $3.5 \%$ FCM by increasing DCAD from 0 to $500 \mathrm{mEq} / \mathrm{kg}$ were $1.7,1.2$, and $3.4 \mathrm{~kg} / \mathrm{cow}$ per day, respectively. The results of this meta-analysis suggest that DCAD has significant effects on intake, milk production and composition, digestion, and feed efficiency in lactating dairy cows.

Key words: DCAD, feed efficiency, meta-analysis, dairy cows

\section{INTRODUCTION}

The original manipulation of DCAD in dairy cow diets was to combat milk fever in periparturient cows (Block, 1984; Delaquis and Block, 1995). More recent research has been focused on the productivity and intake responses to DCAD (Hu and Murphy, 2004; Roche et al., 2005; Harrison et al., 2012; Iwaniuk et al., 2015). Several studies suggested that increasing the DCAD concentration can increase milk yield, milk fat percentage, and optimize DMI in the lactating cow (Tucker et al., 1988b; Hu and Murphy, 2004; Wildman et al., 2007b,c; Apper-Bossard et al., 2010).

Studies with dietary buffers, such as $\mathrm{NaHCO}_{3}$ and $\mathrm{K}_{2} \mathrm{CO}_{3}$, were reported in earlier literature (1960-1990). Buffers were shown to increase DMI, milk production, and feed efficiency, especially in low-forage, high-starch diets (Erdman, 1988). The addition of dietary buffers in the ration of lactating dairy cows undoubtedly altered the DCAD concentration; however, these data were published before the emergence of the DCAD concept and thus have not been included in previous metaanalyses of DCAD effects on dairy cow performance (Hu and Murphy, 2004). Further, many of these studies lacked complete chemical analysis of $\mathrm{Na}, \mathrm{K}, \mathrm{Cl}$, and $\mathrm{S}$ to calculate DCAD using the most common DCAD equation $(\mathrm{Na}+\mathrm{K}-\mathrm{Cl}-\mathrm{S})$. Although the DCAD effects were not originally reported or discussed in the earlier buffer literature, the data reported has value in that it could be potentially used in a retrospective 
(meta) analysis to determine the effects of DCAD concentration and source of strong ion (Na vs. K) on dairy cow performance.

We hypothesized that the addition of data from the dietary buffer literature could be used to enhance our understanding of dairy cow responses to altered DCAD concentrations. Therefore, the objective of our study was to combine earlier buffer feeding literature in lactating dairy cows with more recent studies on DCAD effects to build surface response equations that relate DCAD and dietary strong ion effects $(\mathrm{Na}$ and $\mathrm{K}$ ) on DMI, milk production, milk composition, ruminal characteristics, digestibility, and feed efficiency $(\mathbf{F E})$.

\section{MATERIALS AND METHODS}

\section{Data Collection}

Results from 63 published journal articles involving the use of buffers in the diets of lactating dairy cows were reviewed for inclusion. Journal articles were selected from 4 primary journals: Journal of Dairy Science, Canadian Journal of Animal Science, Journal of Animal Science, and the Journal of Animal Production. Each specific journal article was selected from the reference list of a review article that discussed the effects of dietary buffers (Erdman, 1988).

For a study to be included, treatment means for DMI, milk production, and milk fat concentration had to be reported or be able to be calculated such that FE could be calculated. Feed efficiency was defined as 3.5\% FCM per unit of DMI. The most common reason for the rejection of a study was the lack of treatment DMI or lack of milk fat concentration required to calculate $3.5 \%$ FCM such that FE could be calculated. In many instances, dietary $\mathrm{Na}, \mathrm{K}, \mathrm{Cl}$, or, most frequently, S were not reported. In this case, dietary ingredient information was used to estimate the missing strong ion. Thus, it was essential that specific ingredient information be included so missing strong ion could be estimated using the diet evaluation software in the 2001 Dairy NRC (NRC, 2001). Journal articles were also rejected from the data set if diet information was unclear. For example, some papers did not provide the list of ingredients in a vitamin-mineral premix; therefore, it was unknown if specific DCAD-altering ingredients, such as potassium carbonate or sodium bicarbonate, were present in the vitamin-mineral mix. Some experiments reported ingredients that were not included in the Dairy NRC software and composition information was not available from published feed labels. After removing papers with insufficient animal performance information, feed ingredient, or ingredient composition data, 43 papers involving 89 treatment mean comparisons were used to compile the data set. A summary of the literature studies used in this meta-analysis are shown in Table 1.

\section{Data Assembly}

Several measurements, when available, were collected from each journal article to compile the data set. Data were collected from 4 general categories: (1) diet composition, including dietary $\mathrm{CP}, \mathrm{ADF}, \mathrm{NDF}, \mathrm{Na}, \mathrm{K}$, $\mathrm{Cl}, \mathrm{S}, \mathrm{Ca}, \mathrm{Mg}, \mathrm{P}$, and reported DCAD, were either collected or calculated using the Dairy NRC Software; (2) intake and milk production, including daily milk production and fat concentration and DMI, were collected along with milk protein, lactose, and TS concentrations, when available; (3) digestibility of DM, ADF, NDF, and starch were also collected when reported; and (4) mean ruminal $\mathrm{pH}$ along with mean ruminal acetate, propionate, butyrate molar percentages, and total VFA ( $\mathrm{mEq} / \mathrm{L})$ were entered when reported. The number of observations, mean, standard deviation, and the minimum and maximum values each variable are presented in Table 2.

\section{Missing Data Points}

One of the major problems associated with data set assembly was the lack of measured concentrations for the minerals $\mathrm{Na}, \mathrm{K}, \mathrm{Cl}$, or $\mathrm{S}$. If one of dietary strong ion values was missing, the DCAD concentration $(\mathrm{Na}+\mathrm{K}$ - $\mathrm{Cl}-\mathrm{S}$ ) of that particular diet could not be calculated. Because these experiments were conducted before the emergence of the DCAD concept, several papers did not report one or more of the strong ion values. To overcome this obstacle, a preliminary study was conducted to determine whether the Dairy NRC ration evaluation software could be used to estimate missing dietary ion concentrations. Journal articles which measured the 4 dietary $(\mathrm{Na}, \mathrm{K}, \mathrm{Cl}$, and $\mathrm{S}$ ) ion concentrations were used as test articles. The experimental dietary ingredient information for each treatment was extracted from each article and entered into the Dairy NRC ration evaluation software that was used to estimate the mineral concentrations based on either the software estimates or when the reported value was measured for each feed ingredient. A strong correlation was observed between the estimated ion concentrations from by the NRC software and the measured ion concentrations reported in each paper, as illustrated in Figure 1. The respective coefficient of determination $\left(\mathrm{R}^{2}\right)$ and root mean predicted standard error (RMPSE) of the estimate for $\mathrm{Na}, \mathrm{K}, \mathrm{Cl}$, and $\mathrm{S}$ were $0.88,0.84,0.81$, and 0.47 and $0.06,0.21,0.17$, and 0.06 , respectively. Where DCAD concentrations were reported in a study, NRC software was used estimated concentration of each mineral and 
then DCAD was calculated. There was also good agreement between the NRC-predicted and study-reported DCAD, with an $\mathrm{R}^{2}$ of 0.86 and a standard error of the estimate of 54.7 (Figure 1). Therefore, it was concluded that the NRC software accurately estimated mineral concentrations and the program was used to estimate the mineral concentration in instances where the study did not report them.

\section{Surface Response Equations}

In a recent meta-analysis, $\mathrm{Hu}$ and Murphy (2004) reported that DCAD had a quadratic effect on several production parameters such as milk yield, 4.0\% FCM production, DMI, and milk fat yield (g/d). Upon visual examination of the data, it appeared that DCAD may actually have a curvilinear response with a plateau at higher DCAD concentrations on select responses, such as DMI, $4.0 \% \mathrm{FCM}$, blood $\mathrm{pH}$, blood $\mathrm{HCO}_{3}$, and urine $\mathrm{pH}$ (Hu and Murphy, 2004). Based on this published meta-analysis, a nonlinear model was developed and, after the data set was completed, the data were analyzed using the NLMIXED procedure in SAS (ver. 9.2, SAS Institute Inc., Cary, NC). As the data set was derived from 43 separate published reports, variance caused by experiment within these reports had to be accounted for and removed. Therefore, individual experiments were considered as random samples from the larger population (St-Pierre, 2001) and individual study effects were removed to reduce variance due to

Table 1. Brief summary of the studies included in the meta-analysis data set

\begin{tabular}{|c|c|c|c|}
\hline Paper no. & $\begin{array}{l}\text { Treatment } \\
\text { comparisons }\end{array}$ & Cation sources & Reference \\
\hline 1 & 2 & $\mathrm{NaCO}_{3}+\mathrm{Na}_{2} \mathrm{PO}_{4}$ & Apper-Bossard et al. (2006) \\
\hline 2 & 2 & $\mathrm{Na}_{2} \mathrm{CO}_{3}+\mathrm{Na}_{2} \mathrm{PO}_{4}$ & Apper-Bossard et al. (2010) \\
\hline 3 & 1 & $\mathrm{NaHCO}_{3}+\mathrm{K}_{2} \mathrm{CO}_{3}$ & Chan et al. (2005) \\
\hline 4 & 1 & $\mathrm{NaHCO}_{3}$ & Coppock et al. (1986) \\
\hline 5 & 2 & $\mathrm{NaHCO}_{3}$ & DePeters et al. (1984) \\
\hline 6 & 1 & $\mathrm{NaHCO}_{3}$ & Edwards and Poole (1983) \\
\hline 7 & 1 & $\mathrm{NaHCO}_{3}$ & Eickelberger et al. (1985) \\
\hline 8 & 2 & $\mathrm{NaHCO}_{3}$ & English et al. (1983) \\
\hline 9 & 2 & $\mathrm{NaHCO}_{3}$ & Erdman et al. (1980) \\
\hline 10 & 4 & $\mathrm{NaHCO}_{3}$ & Erdman et al. (1982) \\
\hline 11 & 1 & $\mathrm{~K}_{2} \mathrm{CO}_{3}$ & Erdman et al. (2011) \\
\hline 12 & 1 & $\mathrm{NaHCO}_{3}$ & Escobosa and Coppock (1984) \\
\hline 13 & 1 & $\mathrm{NaHCO}_{3}$ & Fisher and MacKay (1983) \\
\hline 14 & 4 & $\mathrm{NaHCO}_{3}$ & Harris et al. (1983) \\
\hline 15 & 4 & $\mathrm{NaHCO}_{3}$ & Harrison et al. (1986) \\
\hline 16 & 1 & $\mathrm{~K}_{2} \mathrm{CO}_{3}$ & Harrison et al. (2012) \\
\hline 17 & 1 & $\mathrm{NaHCO}_{3}+\mathrm{K}_{2} \mathrm{CO}_{3}$ & Hu and Kung (2009) \\
\hline 18 & 2 & $\mathrm{NaHCO}_{3}+\mathrm{K}_{2} \mathrm{CO}_{3}$ & $\mathrm{Hu}$ et al. (2007a) \\
\hline 19 & 2 & $\mathrm{NaHCO}_{3}+\mathrm{K}_{2} \mathrm{CO}_{3}$ & Hu et al. (2007b) \\
\hline 20 & 2 & $\mathrm{NaHCO}_{3}$ & Kalscheur et al. (1997) \\
\hline 21 & 4 & $\mathrm{NaHCO}_{3}+\mathrm{KHCO}_{3}$ & McKinnon et al. (1990) \\
\hline 22 & 2 & $\mathrm{NaHCO}_{3}+\mathrm{KHCO}_{3}$ & Miller et al. (1965) \\
\hline 23 & 1 & $\mathrm{NaHCO}_{3}+\mathrm{KHCO}_{3}$ & Mooney and Allen (2007) \\
\hline 24 & 1 & $\mathrm{NaHCO}_{3}$ & Roche et al. (2005) \\
\hline 25 & 1 & $\mathrm{NaHCO}_{3}$ & Rogers et al. (1982) \\
\hline 26 & 2 & $\mathrm{NaHCO}_{3}$ & Rogers et al. (1985a) \\
\hline 27 & 2 & $\mathrm{NaHCO}_{3}$ & Rogers et al. (1985b) \\
\hline 28 & 1 & $\mathrm{NaHCO}_{3}$ & Sanchez et al. (1997) \\
\hline 29 & 4 & $\mathrm{NaHCO}_{3}, \mathrm{NaCl}, \mathrm{KCl}$ & Schneider et al. (1986) \\
\hline 30 & 2 & $\mathrm{NaHCO}_{3}$ & Snyder et al. (1983) \\
\hline 31 & 4 & $\mathrm{NaHCO}_{3}$ & Stanley et al. (1972) \\
\hline 32 & 1 & $\mathrm{NaHCO}_{3}$ & Stokes et al. (1986) \\
\hline 33 & 3 & $\mathrm{NaHCO}_{3}$ & Teh et al. (1985) \\
\hline 34 & 2 & $\mathrm{NaHCO}_{3}+\mathrm{KHCO}_{3}$ & Tucker et al. (1988a) \\
\hline 35 & 1 & $\mathrm{NaHCO}_{3}$ & Tucker et al. (1994) \\
\hline 36 & 6 & $\mathrm{NaHCO}_{3}$ & Van Horn et al. (1984) \\
\hline 37 & 2 & $\mathrm{NaHCO}_{3}+\mathrm{KHCO}_{3}$ & West et al. (1986) \\
\hline 38 & 3 & $\mathrm{NaHCO}_{3}+\mathrm{K}_{2} \mathrm{CO}_{3}$ & West et al. (1987) \\
\hline 39 & 2 & $\mathrm{KHCO}_{3}$ & West et al. (1991) \\
\hline 40 & 2 & $\mathrm{NaHCO}_{3}+\mathrm{KHCO}_{3}$ & West et al. (1992) \\
\hline 41 & 2 & $\mathrm{NaHCO}_{3}+\mathrm{K}_{2} \mathrm{CO}_{3}$ & Wildman et al. (2007a) \\
\hline 42 & 2 & $\mathrm{NaHCO}_{3}+\mathrm{K}_{2} \mathrm{CO}_{3}$ & Wildman et al. (2007b) \\
\hline 43 & 2 & $\mathrm{NaHCO}_{3}+\mathrm{K}_{2} \mathrm{CO}_{3}$ & Wildman et al. (2007c) \\
\hline
\end{tabular}

${ }^{1}$ There were 89 total treatment comparisons. 
Table 2. Mean and range of variables within the database

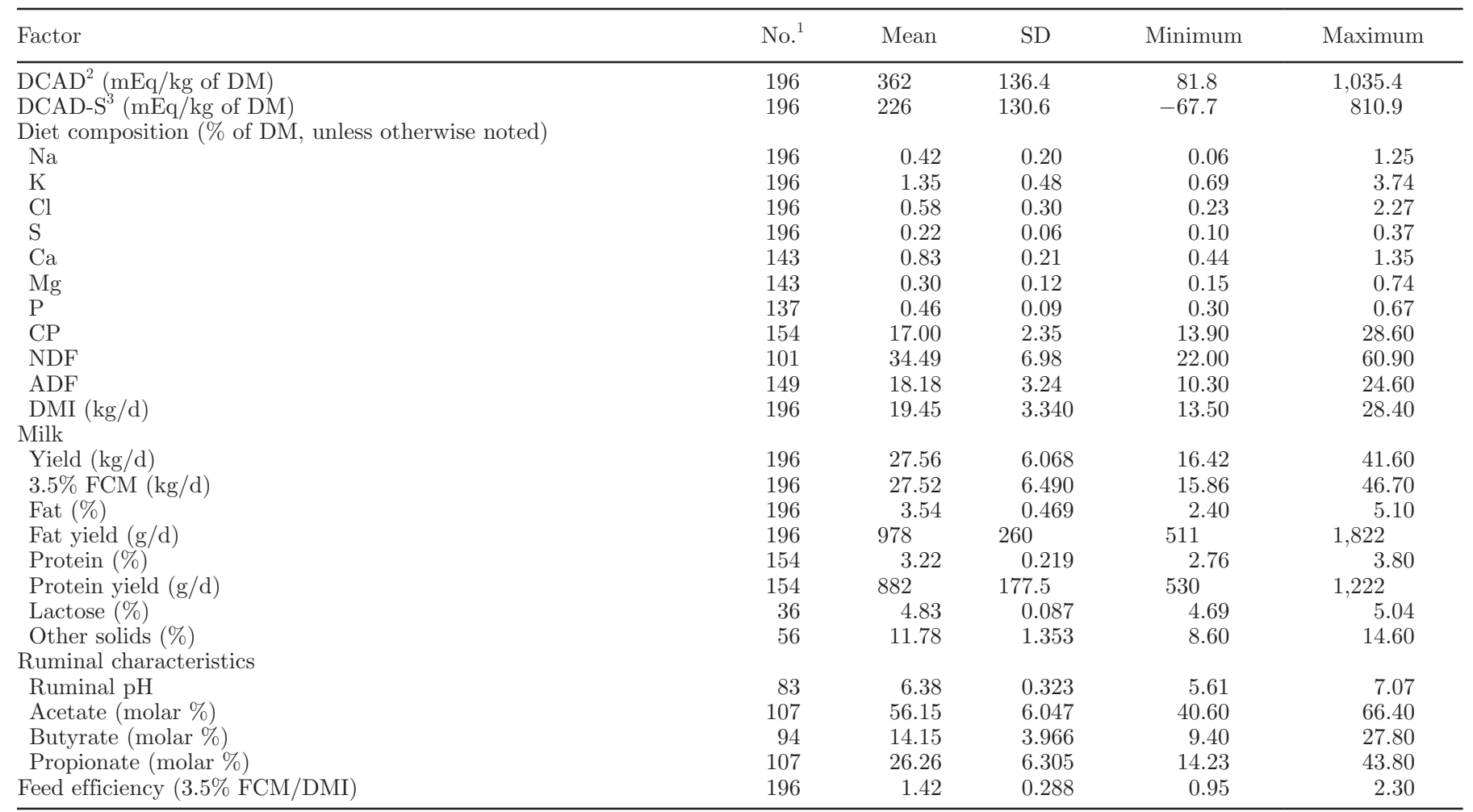

${ }^{1}$ Data were derived from studies conducted on various breeds of dairy cows including 1,991 Holstein, 76 Jersey, 8 Guernsey, 4 Aryshire, and 4 Brown Swiss cow observations embedded within the individual treatment means.

${ }^{2} \mathrm{DCAD}(\mathrm{mEq} / \mathrm{kg})=(\mathrm{Na}+\mathrm{K}-\mathrm{Cl})$.

${ }^{3} \mathrm{DCAD}-\mathrm{S}(\mathrm{mEq} / \mathrm{kg})=(\mathrm{Na}+\mathrm{K}-\mathrm{Cl}-\mathrm{S})$.

study effects. The NLMIXED procedure was used to test surface response models to evaluate the effects of DCAD on DMI and milk production, digestibility, and ruminal characteristics. Initially, we tested a nonlinear model with the following parameters:

$$
\mathrm{Y}=\mathrm{A}_{0}+\mathrm{B}_{0}\left(1-\mathrm{e}^{-\mathrm{kDCAD} \times \mathrm{DCADij}}\right)+\mathrm{s}_{\mathrm{i}}+\mathrm{e}_{\mathrm{ij}},
$$

where $A_{0}=$ overall intercept among studies; $B_{0}=$ magnitude of the potential response to DCAD; $\mathrm{kDCAD}=$ rate constant for DCAD effect; $\mathrm{s}_{\mathrm{i}}=$ random study effects; and $\mathrm{e}_{\mathrm{ij}}=$ random error term, assumed $N\left(0, \sigma^{2}\right)$.

However, the effects of DCAD on several response variables, such as fat yield and FE, were unable to fit the proposed model. Thus, a simpler linear model was developed and tested with the following parameters:

$$
\mathrm{Y}=\mathrm{A}_{0}+\left(\mathrm{kDCAD} \times \mathrm{DCAD}_{\mathrm{ij}}\right)+\mathrm{s}_{\mathrm{i}}+\mathrm{e}_{\mathrm{ij}},
$$

where $\mathrm{A}_{0}=$ overall intercept among studies; $\mathrm{kDCAD}$ $=$ rate constant for the effect of DCAD (slope of the predicted line); $\mathrm{s}_{\mathrm{i}}=$ random study effects; and $\mathrm{e}_{\mathrm{ij}}=$ random error term, assumed $N\left(0, \sigma^{2}\right)$.
The goodness of fit of each variable for both models was compared using Akaike's information criterion correction values. Because the models removed variance due to individual study effect, the study-adjusted values for each variable were used to create the linear and nonlinear equations. In the regression plots, the regression line (solid black line) represents the predicted values of the dependent variable in response to DCAD concentration. The study-adjusted values were also displayed on the plots and they demonstrate the pattern of the dependent variable in response to increased DCAD concentration.

\section{RESULTS AND DISCUSSION}

The regression relationships between the dependent variables and DCAD concentration are presented in Table 3. Each variable was analyzed using either the DCAD-S equation involving sulfur $(\mathrm{Na}+\mathrm{K}-\mathrm{Cl}-\mathrm{S})$ or the more simplistic DCAD equation $(\mathrm{Na}+\mathrm{K}-\mathrm{Cl}$; Supplementary Table S1; http://dx.doi.org/10.3168/ jds.2015-9949). Results from both analyses were extremely similar; however, the results using DCAD-S equation are reported and discussed in the current 
A)

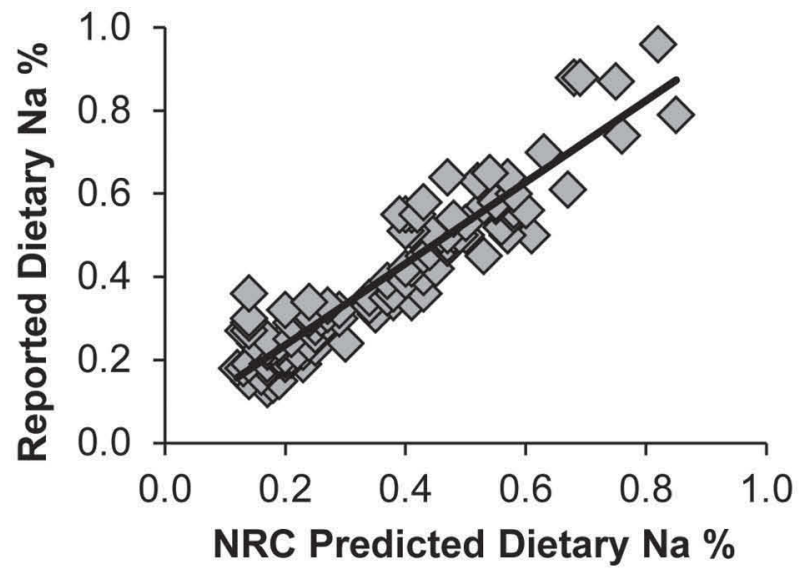

C)

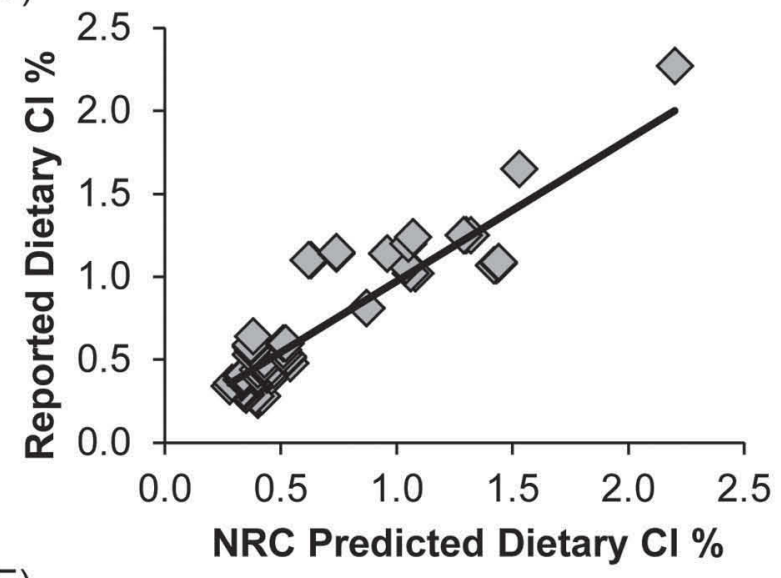

E)

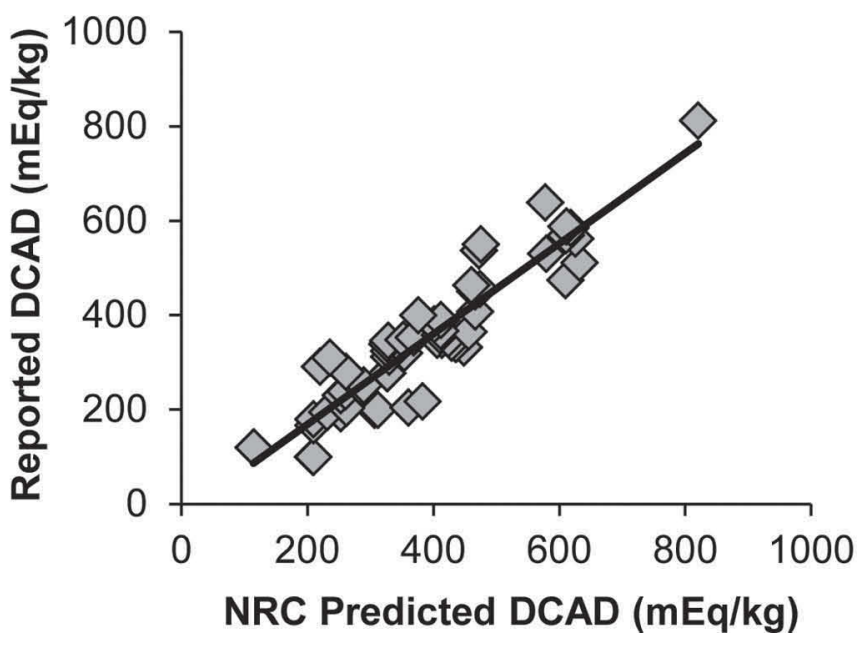

B)

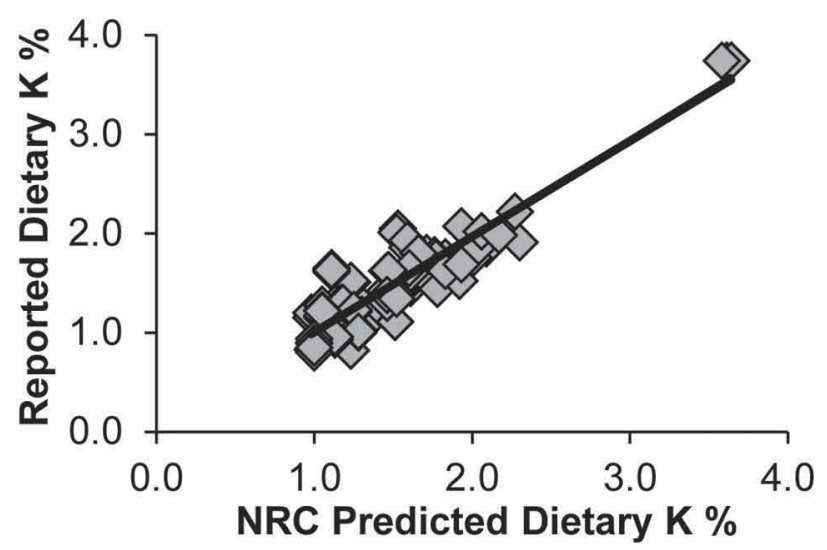

D)

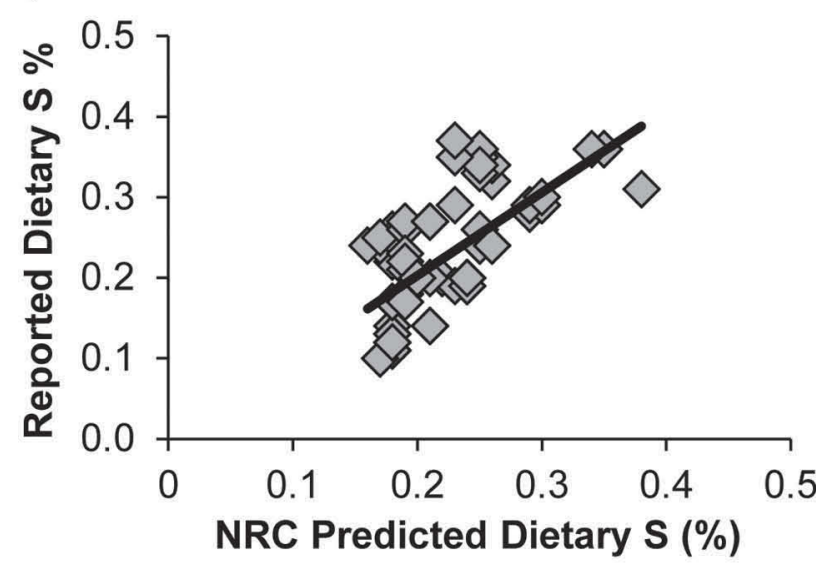

Figure 1. Correlation between reported and NRC (2001) predicted values for dietary concentrations of $(\mathrm{A})$ sodium $[\%=0.9816 \mathrm{x}+0.0395$; intercept $P=0.0027$; intercept $\mathrm{SE}=0.0129$; slope $P<0.001$; slope $\mathrm{SE}=0.0329 ; \mathrm{R}^{2}=0.8754$; root mean (predicted) standard error $(\mathrm{RMSE})=$ $0.0637 ; \mathrm{n}=129],(\mathrm{B})$ potassium $\left(\%=0.9645 \mathrm{x}+0.0371\right.$; intercept $P=0.5113$; intercept $\mathrm{SE}=0.0563 ;$ slope $P<0.001 ;$ slope $\mathrm{SE}=0.0365 ; \mathrm{R}^{2}$ $=0.8383 ; \mathrm{RMSE}=0.2096 ; \mathrm{n}=137)$, (C) chloride $(\%=0.8562 \mathrm{x}+0.1176$; intercept $P=0.0019$; intercept SE $=0.0367 ;$ slope $P<0.001 ;$ slope $\left.\mathrm{SE}=0.0456 ; \mathrm{R}^{2}=0.8113 ; \mathrm{RMSE}=0.1727 ; \mathrm{n}=84\right)$, (D) sulfur $(\%=1.0304 \mathrm{x}-0.0033$; intercept $P=0.9100$; intercept $\mathrm{SE}=0.0288 ;$ slope $P<$ $0.001 ;$ slope $\left.\mathrm{SE}=0.1256 ; \mathrm{R}^{2}=0.4665 ; \mathrm{RMSE}=0.0553 ; \mathrm{n}=79\right),(\mathrm{E}) \mathrm{DCAD}(\mathrm{mEq} / \mathrm{kg}=0.9584 \mathrm{x}-23.421 ;$ intercept $P=0.2660 ;$ intercept $\mathrm{SE}$ $=20.85 ;$ slope $P<0.001 ;$ slope $\left.\mathrm{SE}=0.0512 ; \mathrm{R}^{2}=0.8580 ; \mathrm{RMSE}=54.68 ; \mathrm{n}=60\right)$. 
study. In addition, Figures 2 to 6 show the relationship between DCAD concentration and study-adjusted treatment means for each response variable and, therefore, the regression equations represent the withinstudy responses to DCAD concentration (St-Pierre, 2001). The DCAD concentrations from experiments summarized ranged from -68 to $811 \mathrm{mEq} / \mathrm{kg}$ of $\mathrm{DM}$ $(95 \% \mathrm{CI}=-29$ to $481 \mathrm{mEq} / \mathrm{kg})$. However, the vast majority of the experiments had DCAD concentrations in the range of from 0 to $500 \mathrm{mEq} / \mathrm{kg}$ (Figure 2), which we considered to be a reasonable practical range of inference that could be used in the application of the results of this analysis.

The DMI increased in a curvilinear fashion from 18.4 to $20.1 \mathrm{~kg} / \mathrm{d}$ as DCAD increased from to 0 to $500 \mathrm{mEq} /$ $\mathrm{kg}$ of DM (Figure 2; $P=0.0295 ; \mathrm{R}^{2}=0.41$ ), with calculated incremental responses of $0.61,0.31,0.25,0.19$, and $0.13 \mathrm{~kg} / \mathrm{d}$ increase in DMI with each $100 \mathrm{mEq} /$ $\mathrm{kg}$ of DM increment in DCAD from 0 to $500 \mathrm{mEq} /$ $\mathrm{kg}$ of diet DM. This demonstrates that the greatest incremental increases in DMI from DCAD addition occurred at lower DCAD concentrations. Similar effects of DCAD on DMI were reported in several studies $(\mathrm{Hu}$ et al., 2007a; Wildman et al., 2007b,c; Apper-Bossard et al., 2010). For example, Apper-Bossard et al. (2006) reported DMI values of $22.8,23.7$, and $24 \mathrm{~kg}$ for DCAD concentrations of 4,156 , and $306 \mathrm{mEq} / \mathrm{kg}$ of $\mathrm{DM}(\mathrm{Na}$ $+\mathrm{K}-\mathrm{Cl}-\mathrm{S})$, respectively. Linear regression analysis on those data suggested that DMI increased an average of $0.40 \mathrm{~kg}$ per each incremental increase of $100 \mathrm{mEq} /$ $\mathrm{kg}$ of DCAD $\left(\mathrm{R}^{2}=0.93\right)$, with the greatest increases at lower DCAD concentrations. Those results were similar to the results in the present study, in which DMI increased $0.43 \mathrm{~kg}$ per $100 \mathrm{mEq} / \mathrm{kg}$ increase in DCAD concentration by increasing DCAD from 0 to $300 \mathrm{mEq}$. Therefore, the results of this meta-analysis confirm earlier reports that increasing the DCAD concentration increases DMI.

Increasing the DCAD concentration tended to result in a nonlinear increase $\left(P=0.0647 ; \mathrm{R}^{2}=0.16\right)$ in milk yield (Figure 2 ) with the maximal incremental response of $\left(\mathrm{B}_{0}=1.17 \mathrm{~kg}\right.$; Table 1$)$. Some studies have reported that milk yield can be improved by increasing DCAD concentration (Tucker et al., 1988a; West et al., 1991; Wildman et al., 2007b; Apper-Bossard et al., 2010). In a previous meta-analysis, $\mathrm{Hu}$ and Murphy (2004) showed a maximal milk production response of $1.6 \mathrm{~kg} / \mathrm{d}$ at $337 \mathrm{mEq} / \mathrm{kg}$ of DCAD when data were fitted using a quadratic function. Wildman et al. (2007b) reported that milk yield increased linearly from 24.0 to 25.7 $\mathrm{kg} / \mathrm{d}$ (a $1.7-\mathrm{kg} / \mathrm{d}$ increment) as DCAD $(\mathrm{Na}+\mathrm{K}-\mathrm{Cl}$ - S) increased from 291 to $537 \mathrm{mEq} / \mathrm{kg}$ of DM in diets that contained $15 \% \mathrm{CP}$, which resulted in a $0.69 \mathrm{~kg} / \mathrm{d}$ increase per $100 \mathrm{mEq} / \mathrm{kg}$ increase in DCAD. In the same study, Wildman et al. (2007b) also reported that milk yield increased linearly from 23.8 to $26.6 \mathrm{~kg} / \mathrm{d}$ as DCAD ( $\mathrm{Na}+\mathrm{K}-\mathrm{Cl}-\mathrm{S})$ increased from 310 to 500 $\mathrm{mEq} / \mathrm{kg}$ of $\mathrm{DM}$ in diets that contained $17 \% \mathrm{CP}$, which resulted in a $1.5 \mathrm{~kg} / \mathrm{d}$ increase per $100 \mathrm{mEq} / \mathrm{kg}$ increase in DCAD. Because the results from the current metaanalysis indicated that DCAD concentration increased DMI, it is possible that the increased milk production was a result of increased intake and, thus, more energy and nutrients were available to support production.

In contrast to the curvilinear responses observed for milk production and DMI, milk fat percentage, and fat yield responses increased linearly in response to increased DCAD (Figure 3). At first glance, the treatment means for fat percent and fat yield suggested that these responses might be curvilinear due to the presence of one high DCAD concentration $(811 \mathrm{mEq} / \mathrm{kg}$ of DM). However, Akaike's information criterion correction values were not reduced using the nonlinear model, nor was change in the regression coefficients noted when the highest DCAD concentration was removed from the meta-analysis (Figure 3). Milk fat percentage increased from 3.30 to $3.80 \%$ as DCAD concentration increased from 0 to $500 \mathrm{mEq} / \mathrm{kg}$ of DM. The slope of the regression equation (Table 1, Figure 3) implied a 0.10 percentage unit increase in milk fat percentage per $100-\mathrm{mEq} / \mathrm{kg}$ increase in DCAD $\left(P<0.0001 ; \mathrm{R}^{2}\right.$ $=0.50)$. Similar effects of DCAD on milk fat percentage were reported in several other studies (West et al., 1991; Roche et al., 2005; Apper-Bossard et al., 2006, 2010); for example, Hu et al. (2007a) reported milk fat percentages of $3.12,3.27$, and $3.57 \%$ for DCAD ( $\mathrm{Na}$ $+\mathrm{K}-\mathrm{Cl}-\mathrm{S})$ concentrations of $-30,220$, and 470 $\mathrm{mEq} / \mathrm{kg}$, respectively, in diets that contained $16 \% \mathrm{CP}$. Regression analysis of these data suggests that milk fat percentage increased approximately $0.09 \%$ per 100 $\mathrm{mEq} / \mathrm{kg}$ increase in DCAD. In the same study, Hu et al. (2007a) reported milk fat percentages of 2.85, 3.46, and $3.62 \%$ for DCAD $(\mathrm{Na}+\mathrm{K}-\mathrm{Cl}-\mathrm{S})$ concentrations of $-30,220$, and $470 \mathrm{mEq} / \mathrm{kg}$, respectively, in diets that contained $19 \% \mathrm{CP}$. Regression analysis of those data suggested that milk fat percentage increased approximately $0.15 \%$ per $100-\mathrm{mEq} / \mathrm{kg}$ increase in DCAD. The increases of 0.09 and $0.15 \%$ milk fat per $100 \mathrm{mEq} /$ $\mathrm{kg}$ of DCAD observed by $\mathrm{Hu}$ et al. (2007a) were very similar to the $0.10 \%$ milk fat increase per $100 \mathrm{mEq} / \mathrm{kg}$ of DCAD reported in the current meta-analysis. Similar to milk fat percentage, milk fat yield (g/d) was also linearly increased with DCAD. Milk fat yield increased from 893 to $1,073 \mathrm{~g} / \mathrm{d}$ as DCAD concentration increased from 0 to $500 \mathrm{mEq} / \mathrm{kg}$ of $\mathrm{DM}$, which translated into a $36.0 \mathrm{~g}$ increase per $100 \mathrm{mEq} / \mathrm{kg}$ increase in DCAD concentration $\left(P<0.0001 ; \mathrm{R}^{2}=0.52\right)$. The effect of DCAD on milk fat yield was a result an increase in 
EFFECTS OF DCAD ON PRODUCTION RESPONSES

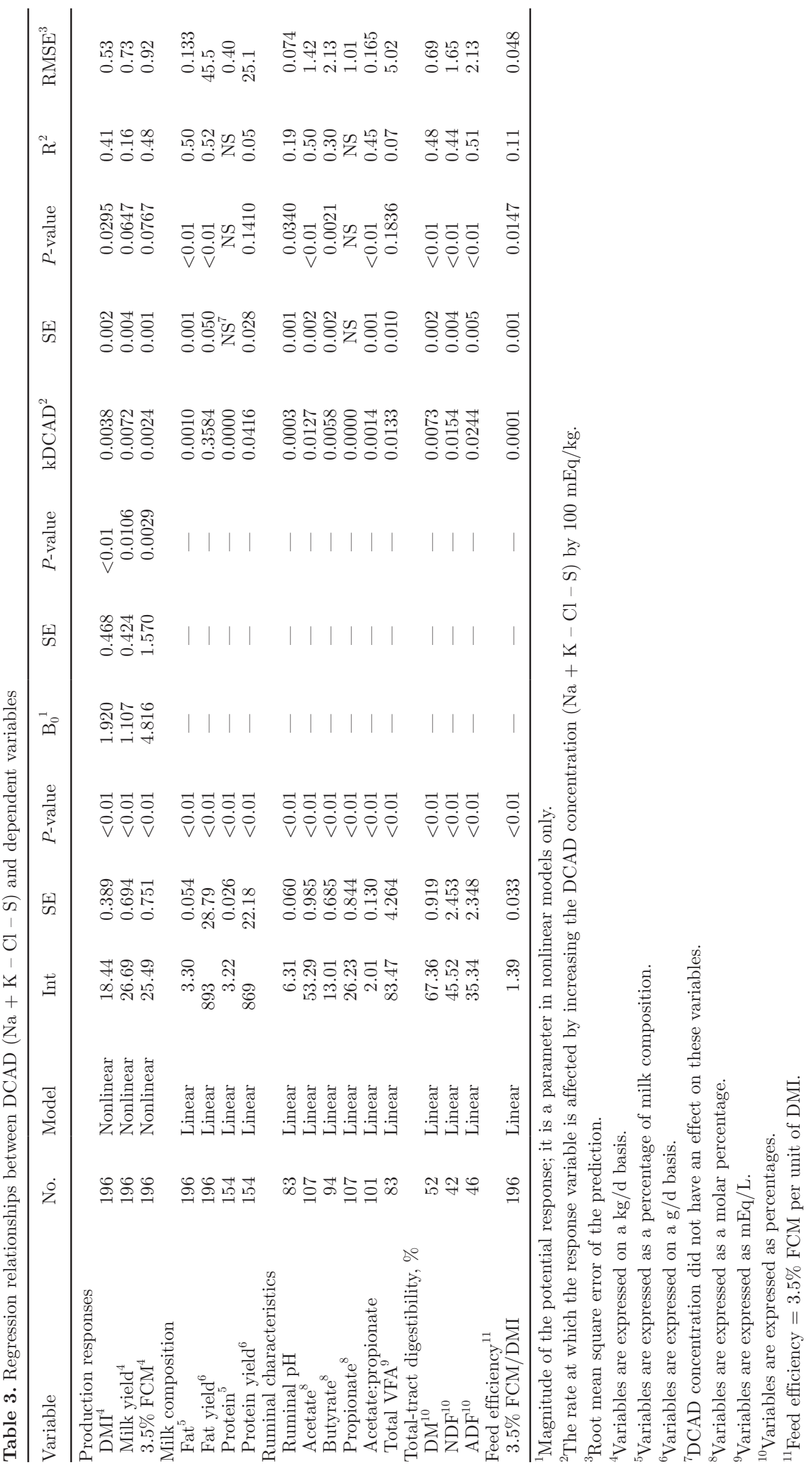


both milk yield and milk fat percentage. The DCAD concentration did not affect milk protein percentage or protein yield $(P>0.05)$.
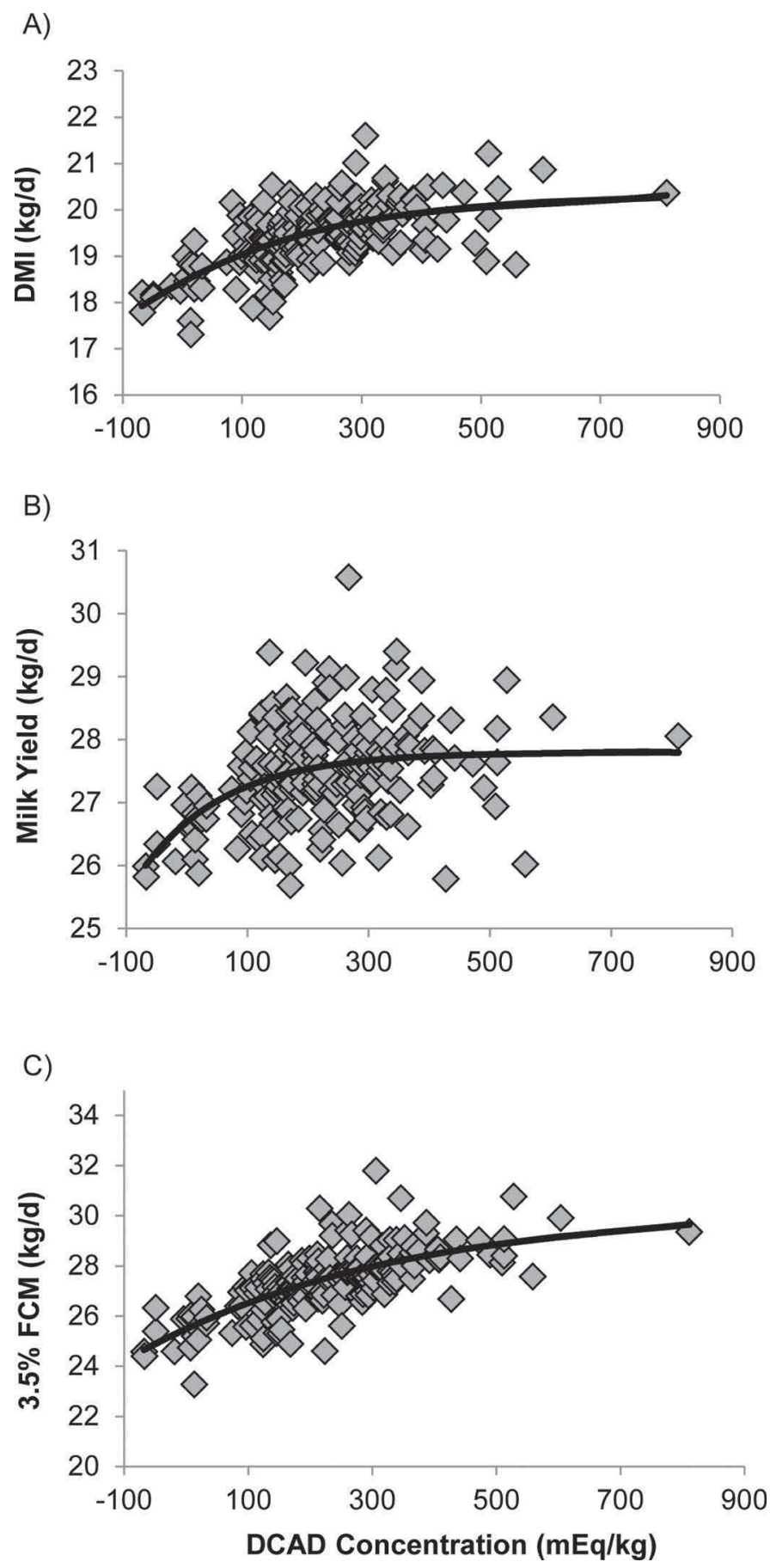

Figure 2. Relationship between DCAD and study-adjusted treatment means for $(\mathrm{A})$ DMI $\left\{\mathrm{kg} / \mathrm{d}=18.442+1.92\left[1-\mathrm{e}^{(-0.0038 \times \mathrm{DCAD})}\right]\right.$; $P=0.0295$ for the DCAD rate constant $(\mathrm{kDCAD}) ; \mathrm{R}^{2}=0.41 ; \mathrm{n}=$ $196\}$, B) milk yield $\left\{\mathrm{kg} / \mathrm{d}=26.69+1.11\left[1-\mathrm{e}^{(-0.0072 \times \text { DCAD })}\right] ; \mathrm{kDCAD}\right.$ $\left.P=0.0647 ; \mathrm{R}^{2}=0.16 ; \mathrm{n}=196\right\}$, and $(\mathrm{C}) 3.5 \% \mathrm{FCM}\{\mathrm{kg} / \mathrm{d}=25.49$ $\left.+4.82\left[1-\mathrm{e}^{(-0.0024 \times \mathrm{DCAD})}\right] ; \mathrm{kDCAD} P=0.0767 ; \mathrm{R}^{2}=0.48 ; \mathrm{n}=196\right\}$.
Because milk fat yield increased and milk production tended to increase in response to increased DCAD concentration, it was no surprise that $3.5 \%$ FCM production also tended to increase with increasing DCAD concentration. As shown in Figure 2, 3.5\% FCM increased from 25.5 to $28.9 \mathrm{~kg} / \mathrm{d}$ as DCAD increased from 0 to $500 \mathrm{mEq} / \mathrm{kg}$ of DM, with incremental responses of 1.02 , $0.92,0.82,0.74$, and $0.67 \mathrm{~kg} / \mathrm{d}$ for each addition $100-$ $\mathrm{mEq} / \mathrm{kg}$ increase in $\operatorname{DCAD}\left(P=0.077 ; \mathrm{R}^{2}=0.48\right)$. Other studies have reported that DCAD increased milk fat yield $(\mathrm{g} / \mathrm{d})$, which resulted in an increase in $4.0 \%$ FCM (West et al., 1991; Roche et al., 2005; Hu et al., 2007a).

Ruminal $\mathrm{pH}$ and VFA data are shown in Figure 4. Ruminal $\mathrm{pH}$ increased $(P=0.034)$ in response to increasing DCAD concentration (Figure 4). As DCAD increased from 0 to $500 \mathrm{mEq} / \mathrm{kg}$, ruminal $\mathrm{pH}$ increased from 6.31 to 6.46 , reflecting a 0.03 -unit increase $(P=$ $0.0340)$ per $100 \mathrm{mEq} / \mathrm{kg}$ of DCAD $\left(\mathrm{R}^{2}=0.19\right)$. Similar results were reported in other studies (Roche et al., 2005; Apper-Bossard et al., 2006) and an earlier review of buffer feeding responses by Erdman (1988).

In the current meta-analysis, it was previously mentioned that milk fat percentage and yield were linearly increased as a result of increased DCAD concentration. Addition of the rumen buffers $\mathrm{NaHCO}_{3}$ and $\mathrm{MgO}$ that increased DCAD by $165 \mathrm{mEq} / \mathrm{kg}$ increased rumen $\mathrm{pH}$ (Kalscheur et al., 1997) and reduced duodenal flows of biohydrogenation intermediates, such as trans 18:1 and 18:2 CLA FA (Piperova et al, 2002), in high-concentrate diets. Subsequent studies reported that low ruminal $\mathrm{pH}$ alters biohydrogenation, resulting in increased amounts of select ruminal CLA isomers (trans-10,cis-12 CLA; trans-9,cis-11 CLA; and cis-10,trans-12 CLA) that have been linked to milk fat depression (Baumgard et al., 2000; Saebø et al., 2005; Perfield et al., 2007; Jenkins et al., 2014). As ruminal $\mathrm{pH}$ increases, a shift in the lipid biohydrogenation pattern occurs such that the CLA isomers that have been linked to milk fat depression decrease and normal (cis-9,trans-11) CLA isomers increase (Harrison et al., 2012; Jenkins et al., 2014). This shift in CLA isomer production may explain the increases in milk fat percentage and yield observed in the current meta-analysis; however, milk FA data were not collected or analyzed to investigate this hypothesis.

In addition to increasing milk fat percentage and yield, increased ruminal $\mathrm{pH}$ has been shown to be related to alterations in rumen VFA patterns (Erdman, 1988; Sanchez and Beede, 1996; Apper-Bossard et al., 2010). In the present meta-analysis, both ruminal acetate and butyrate molar percentages were linearly increased as a result of increased DCAD concentration. As shown in Figure 4, ruminal acetate increased from 52.3 to 58.7 molar percentage units as DCAD increased from 0 to 
$500 \mathrm{mEq} / \mathrm{kg}\left(P<0.0001 ; \mathrm{R}^{2}=0.50\right)$. Ruminal butyrate increased from 13.0 to 15.9 molar percentage units as DCAD increased $\left(P=0.0021 ; \mathrm{R}^{2}=0.30\right.$; Figure 4$)$. Therefore, ruminal acetate and butyrate increased by 1.27 and 0.58 molar percentage units, respectively, per $100 \mathrm{mEq} / \mathrm{kg}$ DCAD, and this change in VFA pattern most likely occurred due to increased ruminal $\mathrm{pH}$. The DCAD did not significantly affect molar percentages of propionate $(P>0.05)$; however, DCAD concentration did affect acetate-to-propionate ratios. As DCAD increased from 0 to $500 \mathrm{mEq} / \mathrm{kg}$, the acetate-to-propionate ratio increased from 2.01 to 2.71 , which translated into a 0.14 -unit increase per $100 \mathrm{mEq} / \mathrm{kg}$ DCAD $(P<$ $\left.0.0001 ; R^{2}=0.45\right)$. This result is due to the significant increase in acetate, which serves as the numerator in the acetate-to-propionate ratio. Total VFA concentration $(\mathrm{mEq} / \mathrm{L})$ was not affected by DCAD $(P>0.05)$.

A)

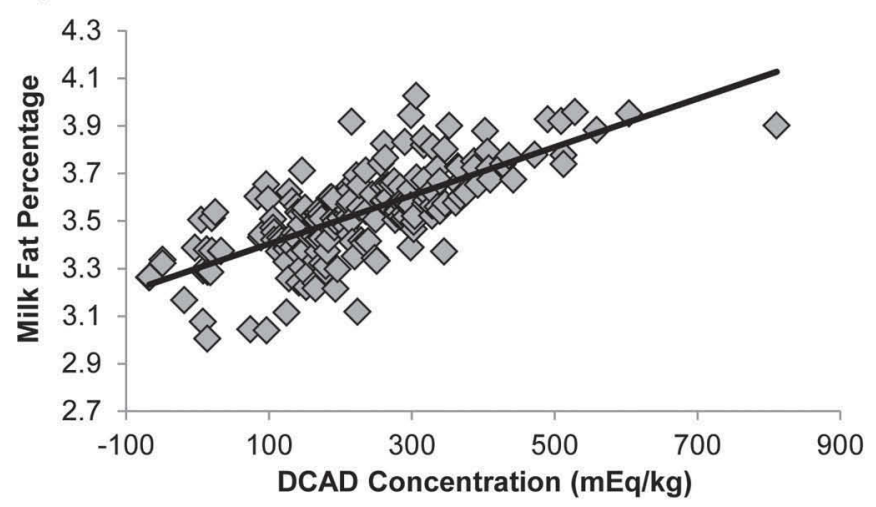

B)

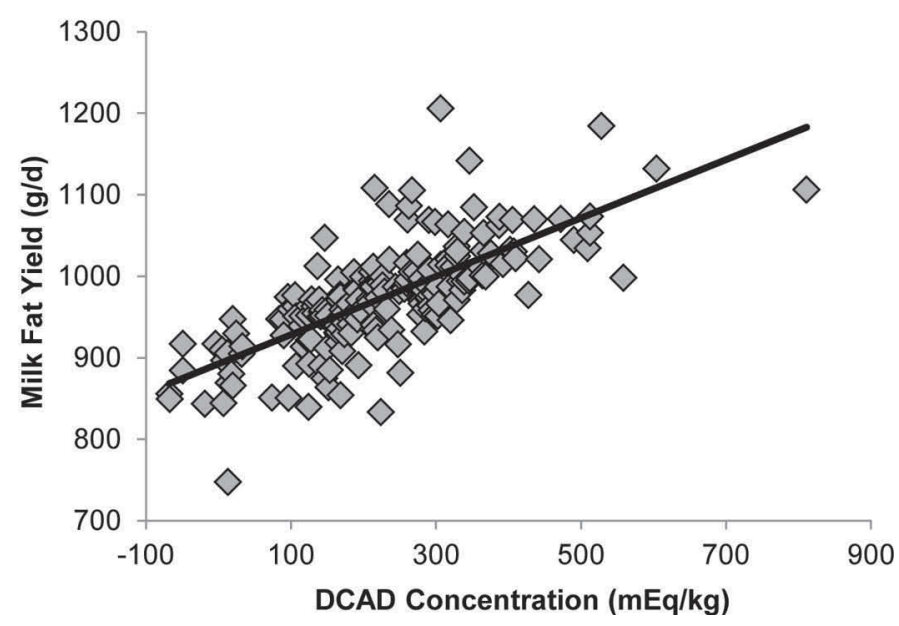

Figure 3. Relationship between DCAD and study-adjusted treatment means for $(\mathrm{A})$ milk fat percentage $[0.0010 \times \mathrm{DCAD}(\mathrm{mEq} / \mathrm{kg}$ of $\mathrm{DM})+3.3024 ; P<0.0001$ for the DCAD rate constant $(\mathrm{kDCAD}) ; \mathrm{R}^{2}$ $=0.50 ; \mathrm{n}=196]$ and $(\mathrm{B})$ milk fat yield $[0.3584 \times \mathrm{DCAD}(\mathrm{mEq} / \mathrm{kg}$ of $\left.\mathrm{DM})+892.39 ; \mathrm{kDCAD} P<0.0001 ; \mathrm{R}^{2}=0.52 ; \mathrm{n}=196\right]$.
The current meta-analysis indicated that increasing DCAD can alter ruminal characteristics such as $\mathrm{pH}$ and VFA production.

The DCAD effects on digestibility were also evaluated; however, the range in DCAD (13 to $436 \mathrm{mEq} /$ $\mathrm{kg}$ ) across study treatment means in which digestibility was measured was narrower than for production characteristics. Across this range, increased DCAD resulted in increased DM digestibility (67.5 to 70.5 ), with a 0.73 -percentage unit increase per $100-\mathrm{mEq} / \mathrm{kg}$ increase in DCAD $\left(P<0.001 ; \mathrm{R}^{2}=0.48\right)$. The DCAD effects on starch digestibility were not reported due to insufficient raw data. Similar to effects on DM digestibility, both NDF and ADF digestibility increased linearly as DCAD concentration increased. Neutral detergent fiber digestibility increased from 45.7 to $52.2 \%$ as DCAD increased from 13 to $436 \mathrm{mEq} / \mathrm{kg}$, which resulted in a 1.54-percentage unit increase in NDF digestibility per $100 \mathrm{mEq} / \mathrm{kg}$ increase in DCAD concentration $(P=$ $0.0014 ; \mathrm{R}^{2}=0.44 ;$ Figure 5$)$. With an average dietary NDF content of $34.5 \%$ across studies (Table 2), the change in NDF digestibility would account for $(0.345$ $\times 1.54=0.53 \%$ ) nearly $70 \%$ of improvement in DM digestibility with increased DCAD. Acid detergent fiber digestibility improved from 35.7 to $44.2 \%$ as DCAD increased from 13 to $364 \mathrm{mEq} / \mathrm{kg}$, which resulted in a 2.44-percentage-unit increase in ADF digestibility per $100 \mathrm{mEq} / \mathrm{kg}$ increase in DCAD concentration $(P$ $=0.0001 ; \mathrm{R}^{2}=0.51 ;$ Figure 5$)$. The rate of increase in ADF digestibility was greater than that for NDF digestibility with increasing DCAD. As cellulose represents the only digestible component of ADF, improved cellulose digestibility could be implied as the primary reason for increased NDF digestibility with increased DCAD. Previous studies have suggested that changes in fiber digestibility occur as a result of changes in ruminal pH (Erdman et al., 1982; Rogers et al., 1982, 1985b; West et al., 1987; Allen, 1997), and changes in rumen pH (Figure 4) are consistent with that observation.

Finally, the results from the current meta-analysis demonstrated that DCAD concentration affected dairy FE. As DCAD increased from 0 to $500 \mathrm{mEq} / \mathrm{kg}$, FE increased from 1.39 to 1.44 units, equivalent to a 0.01-unit increase per $100 \mathrm{mEq} / \mathrm{kg}$ increase in DCAD concentration $\left(P=0.015 ; \mathrm{R}^{2}=0.11 ;\right.$ Figure 6$)$. The increase in FE was likely due to both increased DMI and an improvement in dietary energy availability from improved digestibility. Therefore, the results from the current meta-analysis suggest that dairy FE can be improved by increasing the DCAD concentration in the diets of lactating dairy cows.

In the present meta-analysis, both overall DCAD effects and individual cation effects on production responses were investigated. As both $\mathrm{Na}$ and $\mathrm{K}$ are strong 
A)

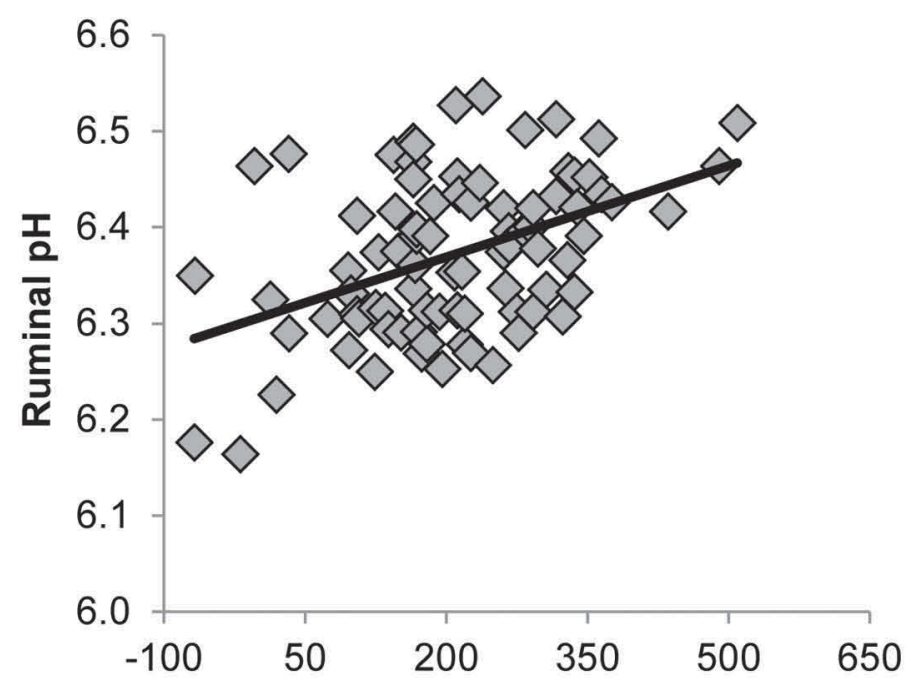

C)

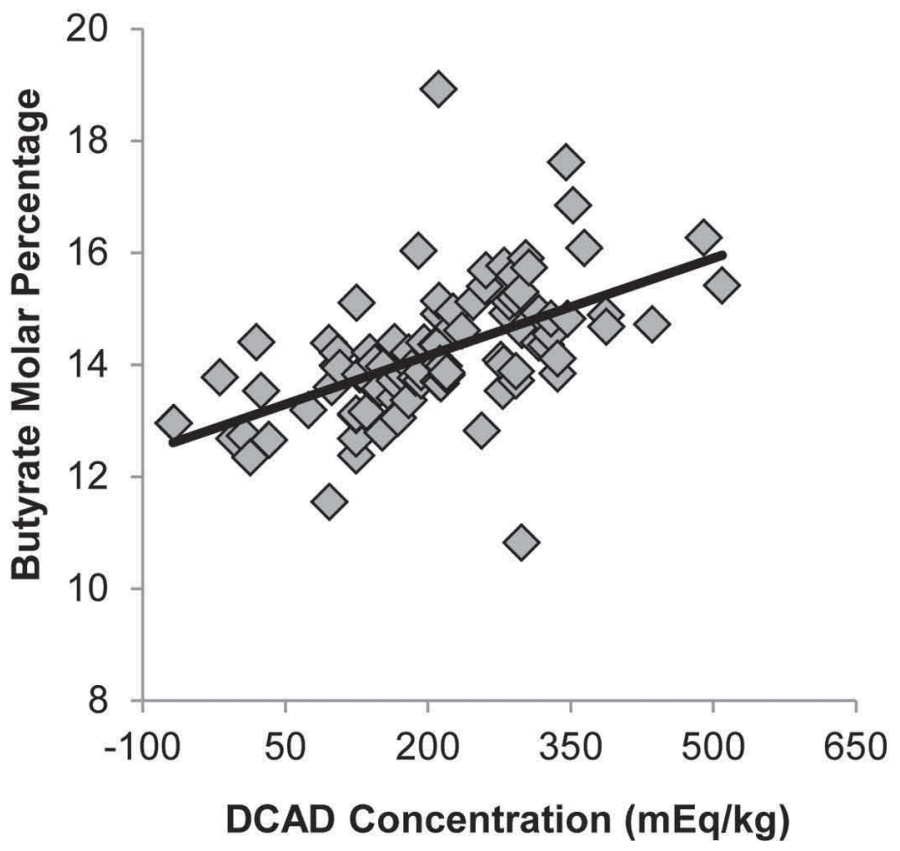

B)

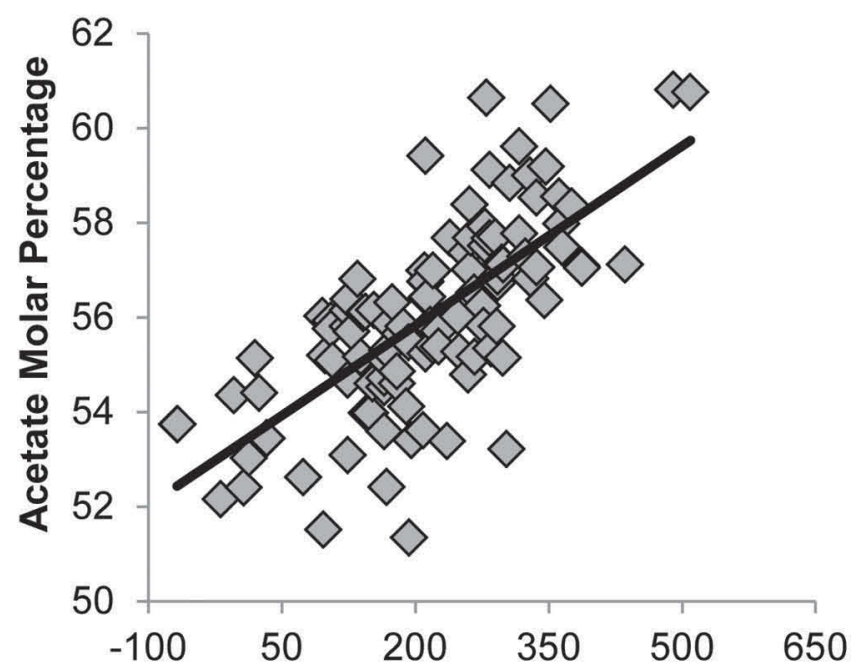

D)

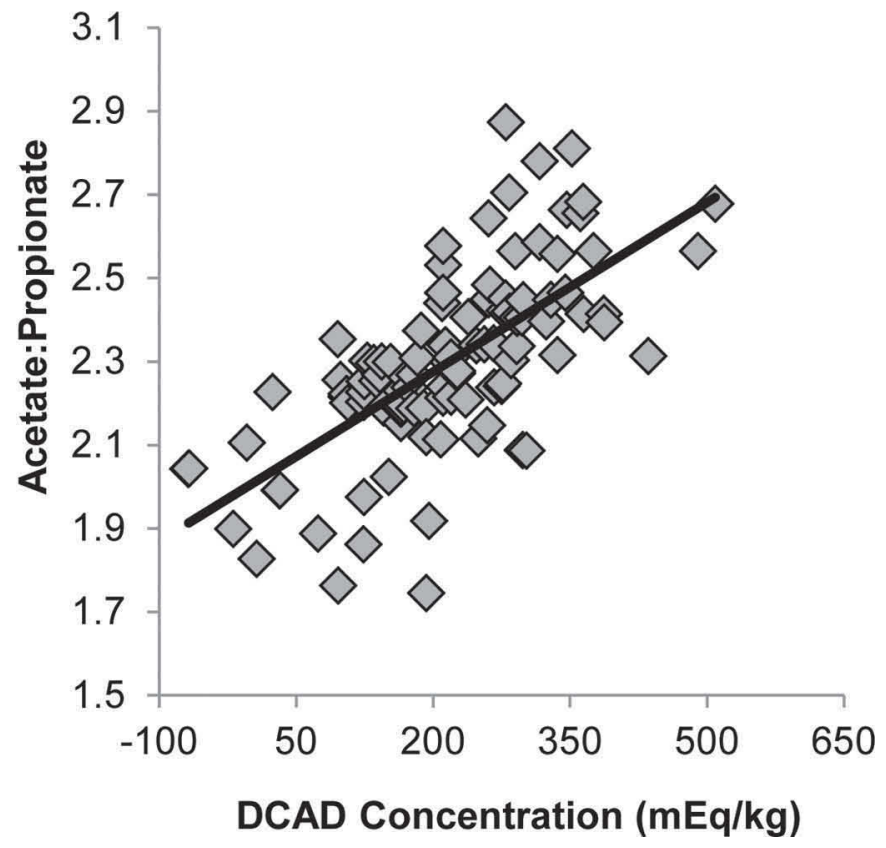

Figure 4. Relationship between DCAD and study-adjusted treatment means for (A) ruminal $\mathrm{pH}[0.0003 \times \mathrm{DCAD}(\mathrm{mEq} / \mathrm{kg}$ of $\mathrm{DM})+$ 6.3058; $P=0.0340$ for the DCAD rate constant $\left.(\mathrm{kDCAD}) ; \mathrm{R}^{2}=0.19 ; \mathrm{n}=83\right],(\mathrm{B})$ acetate molar percentage $[0.01267 \times \mathrm{DCAD}(\mathrm{mEq} / \mathrm{kg}$ of $\mathrm{DM})$ $\left.+53.2919 ; \mathrm{kDCAD} P<0.0001 ; \mathrm{R}^{2}=0.50 ; \mathrm{n}=107\right],(\mathrm{C})$ butyrate molar percentage $[0.005793 \times \mathrm{DCAD}(\mathrm{mEq} / \mathrm{kg}$ of $\mathrm{DM})+13.0070 ; \mathrm{kDCAD} P$ $\left.=0.0021 ; \mathrm{R}^{2}=0.30 ; \mathrm{n}=94\right]$, and $(\mathrm{D})$ ratio of acetate to propionate molar percentages $[0.001352 \times \mathrm{DCAD}(\mathrm{mEq} / \mathrm{kg}$ of $\mathrm{DM})+2.0053 ; \mathrm{kDCAD}$ $\left.P<0.0001 ; \mathrm{R}^{2}=0.45 ; \mathrm{n}=101\right]$.

cation in the DCAD equation, it has been assumed that DCAD responses were similar regardless of cation used. In the dairy industry, supplementation with K sources is approximately 4 times more expensive as compared with supplementation with $\mathrm{Na}$ sources. Iwaniuk et al.
(2014) recently reported that substitution of dietary $\mathrm{Na}$ for $\mathrm{K}$ on an equal milliequivalent basis resulted in increased milk fat content and yield. However, other studies (West et al., 1992; Sanchez et al., 1997; Hu and Kung, 2009) failed to show a differential response to Na 
versus $\mathrm{K}$ as the dietary cation. Unfortunately, we could not delineate individual cation effects ( $\mathrm{Na}$ vs. K) due to insufficient numbers of experiments with $\mathrm{K}$ supplementation and the number of experiments with direct
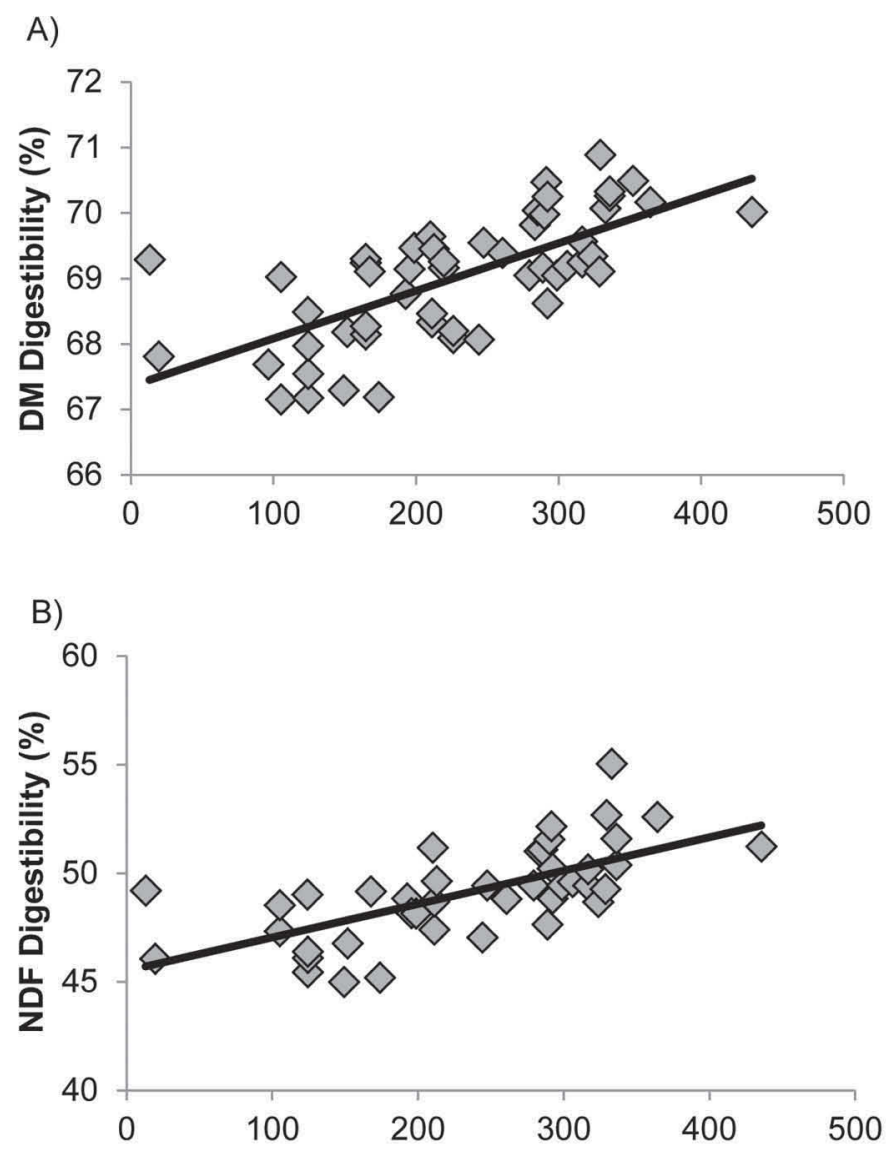

C)

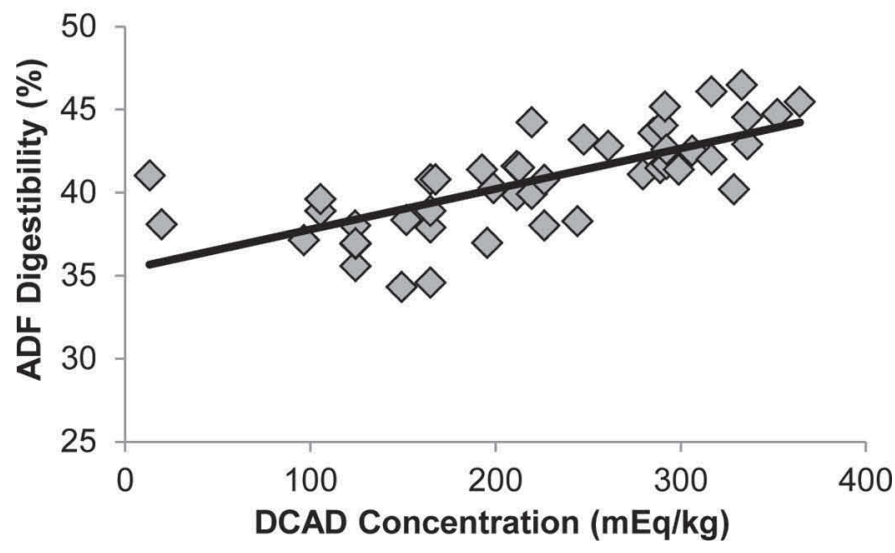

Figure 5. Relationship between DCAD and study-adjusted treatment means for (A) DM digestibility $[0.007276 \times$ DCAD $(\mathrm{mEq} / \mathrm{kg}$ of $\mathrm{DM})+67.3551 ; P=0.0002$ for the DCAD rate constant $(\mathrm{kDCAD})$ $\left.\mathrm{R}^{2}=0.48 ; \mathrm{n}=52\right],(\mathrm{B}) \mathrm{NDF}$ digestibility $[0.01536 \times \mathrm{DCAD}(\mathrm{mEq} /$ $\mathrm{kg}$ of $\left.\mathrm{DM})+45.5203 ; \mathrm{kDCAD} P=0.0014 ; \mathrm{R}^{2}=0.44 ; \mathrm{n}=42\right]$, and (C) ADF digestibility $[0.02443 \times \mathrm{DCAD}(\mathrm{mEq} / \mathrm{kg}$ of $\mathrm{DM})+35.3365$; $\left.\mathrm{kDCAD} P=0.0001 ; \mathrm{R}^{2}=0.51 ; \mathrm{n}=46\right]$. comparisons of $\mathrm{Na}$ versus $\mathrm{K}$ supplementation; thus, the relative effectiveness of $\mathrm{Na}$ versus $\mathrm{K}$ in terms of production responses could not be determined in this analysis.

The exact mechanisms by which DCAD affects production responses is unknown, as manipulating DCAD alters both the cow's rumen environment and acidbase homeostasis (Erdman, 1988; Sanchez and Beede, 1996; $\mathrm{Hu}$ and Murphy, 2005; Roche et al., 2005; Hu et al., 2007a; Apper-Bossard et al., 2010). Typically, increased DCAD concentration in lactating cow diets is achieved by supplementing dietary buffers such as sodium or potassium bicarbonates, carbonates, and sesquicarbonates. In addition to serving as a source of mineral cations ( $\mathrm{Na}$ or $\mathrm{K}$ ), these buffers also contribute carbonate anions which can be used by the animal to improve acid-base balance. Dietary cations ( $\mathrm{Na}$ and $\mathrm{K}$ ) and anions ( $\mathrm{Cl}$ and $\mathrm{S}$ ) also play important roles in regulating acid-base status (Tucker et al., 1988a,b; Hu et al., 2007b), which in turn might improve production efficiency (Erdman, 1988; Hu and Murphy, 2004; ApperBossard et al., 2010). Strong ions ( $\mathrm{Na}, \mathrm{K}$, and $\mathrm{Cl}$ ) and carbon dioxide and bicarbonate cross the rumen wall, and $\mathrm{NaHCO}_{3}$ and $\mathrm{Na}_{2} \mathrm{HPO}_{4}$ are major constituents of ruminant saliva (Erdman, 1988). Therefore, it would difficult to envision changes in rumen acid-base status that would not also be reflected in changes in animal's acid-base homeostasis and vice-versa.

Some production responses to DCAD can be directly attributed to effects on rumen fermentation. For example, increased rumen biohydrogenation of dietary PUFA reduces the flow of biohydrogenation intermediates, such as trans-10,cis-12 CLA, to the duodenum (Piperova et al., 2002), which has been shown to interfere with milk fat synthesis (Baumgard et al., 2000). As previously stated, NDF digestibility increased by 1.5

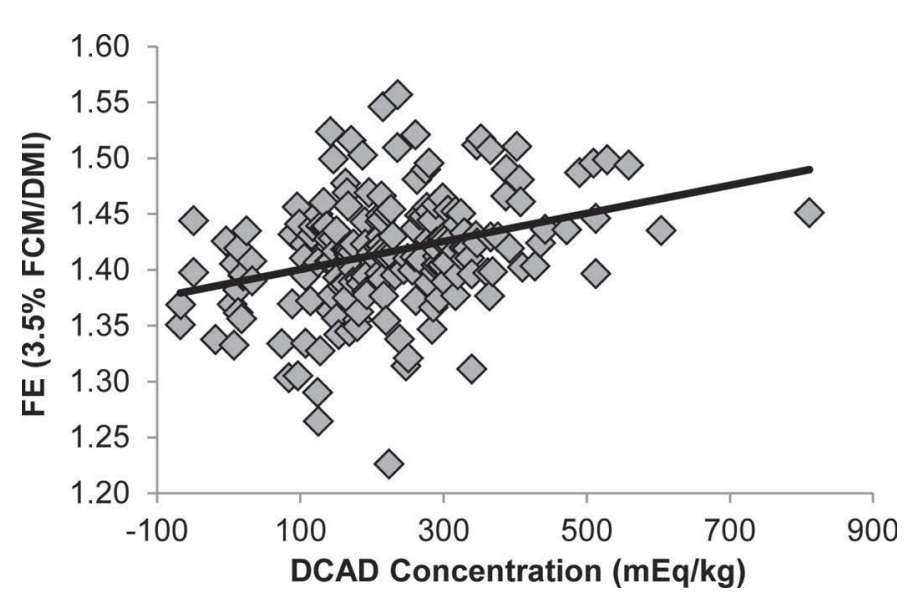

Figure 6. Relationship between DCAD and study-adjusted treatment means for feed efficiency (3.5\% FCM per unit of DMI). Feed efficiency $=0.000126 \times \mathrm{DCAD}(\mathrm{mEq} / \mathrm{kg}$ of $\mathrm{DM})+1.3878 ; P=0.0147$ for the DCAD rate constant $(\mathrm{kDCAD}) ; \mathrm{R}^{2}=0.11 ; \mathrm{n}=196$. 
percentage units per $100 \mathrm{mEq} / \mathrm{kg}$ increase in DCAD. Oba and Allen (1999) suggested that a 1-percentage unit increase in fiber digestibility resulted in a 0.17 and $0.25 \mathrm{~kg} / \mathrm{d}$ increases in DMI and $4.0 \% \mathrm{FCM}$, respectively. Using Oba and Allen (1999) coefficients and assuming a 7.5-percentage-unit increase in NDF digestibility by increasing DCAD from 0 to $500 \mathrm{mEq} /$ $\mathrm{kg}$, the expected increase in DMI and 3.5\% FCM would be 1.3 and $1.9 \mathrm{~kg} / \mathrm{d}$, respectively. This contrasts with the current meta-analysis predicted responses of 1.7 $\mathrm{kg} / \mathrm{d}$ of DMI and $3.4 \mathrm{~kg} / \mathrm{d}$ of $3.5 \% \mathrm{FCM}$, and suggests that about $75 \%$ of the increase in DMI and $55 \%$ of the FCM response to DCAD is due to effects of DCAD on NDF digestibility. This illustrates that some but not all of the production responses to DCAD can be accounted for by changes in rumen fermentation.

\section{CONCLUSIONS}

The results of this meta-analysis, based on the data available, suggest that DCAD has a significant effect on a variety of performance indicators including DMI, 3.5\% FCM production, milk composition, ruminal characteristics, feed digestibility, and FE. Changes in ruminal $\mathrm{pH}$ and VFA concentrations suggest that some of the intake and production responses to DCAD are a result of improved rumen fermentation. Fiber digestibility is markedly increased with increased DCAD concentration, resulting in increased DM digestibility and likely energy supply to the cow. Although the mechanism(s) remains unclear, DCAD most likely alters production and digestibility by changing the rumen environment and improving acid-base homeostasis in the dairy cow.

\section{ACKNOWLEDGMENTS}

The authors thank Arm \& Hammer Animal Nutrition (Piscataway, NJ) for partial support of this study.

\section{REFERENCES}

Allen, M. S. 1997. Relationship between fermentation acid production in the rumen and the requirement for physically effective fiber. J. Dairy Sci. 80:1447-1462.

Apper-Bossard, E., P. Faverdin, F. Meschy, and J. L. Peyraud. 2006. Changing dietary cation-anion difference for dairy cows fed with two contrasting levels of concentrate in diets. J. Dairy Sci. 89:749760 .

Apper-Bossard, E., P. Faverdin, F. Meschy, and J. L. Peyraud. 2010. Effects of dietary cation-anion difference on ruminal metabolism and blood acid-base regulation in dairy cows receiving 2 contrasting levels of concentrate in diets. J. Dairy Sci. 93:4196-4210.

Baumgard, L. H., B. A. Corl, D. A. Dwyer, A. Saebo, and D. E. Bauman. 2000. Identification of the conjugated linoleic acid isomer that inhibits milk fat synthesis. Am. J. Physiol. Regul. Integr. Comp. Physiol. 278:R179-R184.
Block, E. 1984. Manipulating dietary anions and cations for prepartum dairy cows to reduce incidence of milk fever. J. Dairy Sci 67:2939-2948

Chan, P. S., J. W. West, J. K. Bernard, and J. M. Fernandez. 2005. Effects of dietary cation-anion difference on intake, milk yield, and blood components of the early lactation cow. J. Dairy Sci. 88:4384-4392.

Coppock, C. E., G. T. Schelling, F. M. Byers, J. W. West, J. M. Labore, and C. E. Gates. 1986. A naturally occurring mineral as a buffer in the diet of lactating dairy cows. J. Dairy Sci. 69:111-123.

Delaquis. A. M., and E. Block. 1995. Dietary cation-anion difference, acid-base status, mineral metabolism, renal function, and milk production of lactating cows. J. Dairy Sci. 78:2259-2284.

DePeters, E. J., A. H. Fredeen, D. L. Bath, and N. E. Smith. 1984. Effect of sodium bicarbonate addition to alfalfa hay-based diets on digestibility of dietary fractions and rumen characteristics. J. Dairy Sci. 67:2344-2355.

Edwards, S. A., and D. A. Poole. 1983. Effects of sodium bicarbonate in the diet of dairy cows. Anim. Prod. 37:183.

Eickelberger, R. C., L. D. Muller, T. F. Sweeney, and S. M. Abrams. 1985. Addition of buffers to high quality alfalfa hay-based diets for dairy cows in early lactation. J. Dairy Sci. 68:1722-1731.

English, J. E., T. J. Fronk, D. G. Braund, and J. E. Nocek. 1983. Influence of buffering early lactation rations with sodium bicarbonate and magnesium oxide and subsequent withdrawal or addition effects. J. Dairy Sci. 66:505-513.

Erdman, R. A. 1988. Dietary buffering requirements of the lactating dairy cow: A review. J. Dairy Sci. 71:3246-3266.

Erdman, R. A., R. L. Botts, R. W. Hemken, and L. S. Bull. 1980. Effect of dietary sodium bicarbonate and magnesium oxide on production and physiology in early lactation. J. Dairy Sci. 63:923-930.

Erdman, R. A., R. W. Hemken, and L. S. Bull. 1982. Dietary sodium bicarbonate and magnesium oxide for early postpartum lactating dairy cows: Effects on production, acid-base metabolism, and digestion. J. Dairy Sci. 65:712-731

Erdman, R. A., L. S. Piperova, and R. A. Kohn. 2011. Corn silage versus corn silage:alfalfa hay mixtures for dairy cows: Effects of dietary potassium, calcium, and cation-anion difference. J. Dairy Sci. 94:5105-5110.

Escobosa, A., and C. E. Coppock. 1984. Effects of dietary sodium bicarbonate and calcium chloride on physiological responses of lactating dairy cows in hot weather. J. Dairy Sci. 67:574-584.

Fisher, L. J., and V. G. MacKay. 1983. The investigation of sodium bicarbonate or bentonite as supplements in silages fed to lactating dairy cows. Can. J. Anim. Sci. 63:939.

Harris, B., Jr., H. H. Van Horn, K. E. Manookian, S. P. Marshall, M. J. Taylor, and C. J. Wilcox. 1983. Sugar-cane silage, sodium hydroxide- and steam pressure-treated sugarcane bagasse, corn silage, cotton seed hulls, sodium bicarbonate and Aspergillis oryzae product in complete rations for lactating cows. J. Dairy Sci. 66:1474-1485

Harrison, G. A., R. W. Hemken, and R. J. Harmon. 1986. Sodium bicarbonate and alfalfa hay additions to wheat silage diets fed to lactating dairy cows. J. Dairy Sci. 69:2321-2333.

Harrison, J., R. White, R. Kincaid, and E. Block. 2012. Effectiveness of potassium carbonate sesquihydrate to increase dietary cationanion difference in early lactation cows. J. Dairy Sci. 95:3919-3925.

Hu, W., and L. Kung. 2009. Effect of dietary ratio of Na:K on feed intake, milk production, and mineral metabolism in mid-lactation dairy cows. J. Dairy Sci. 92:2711-2718.

Hu, W., and M. R. Murphy. 2004. Dietary cation-anion difference effects on performance and acid-base status of lactating dairy cows: A meta-analysis. J. Dairy Sci. 87:2222-2229.

Hu, W., and M. R. Murphy. 2005. Statistical evaluation of early- and mid-lactation dairy cow response to dietary sodium bicarbonate addition. Anim. Feed Sci. Technol. 119:43-54.

Hu, W., M. R. Murphy, P. D. Constable, and E. Block. 2007a. Dietary cation-anion difference and dietary protein effects on performance and acid-base status of dairy cows. J. Dairy Sci. 90:3355-3366. 
Hu, W., M. R. Murphy, P. D. Constable, and E. Block. 2007b. Dietary cation-anion difference effects on performance and acid-base status of dairy cows postpartum. J. Dairy Sci. 90:3367-3375.

Iwaniuk, M. E., A. E. Weidman, and R. A. Erdman. 2015. The effect of dietary cation-anion difference concentration and cation source on milk production and feed efficiency in lactating dairy cows. J. Dairy Sci. 98:1950-1960.

Jenkins, T. C., W. C. Bridges, J. H. Harrison, and K. M. Young. 2014. Addition of potassium carbonate to continuous cultures of mixed ruminal bacteria shifts volatile fatty acids and daily production of biohydrogenation intermediates. J. Dairy Sci. 97:975-984.

Kalscheur, K. F., B. B. Teter, L. S. Piperova, and R. A. Erdman. 1997. Effect of dietary forage concentration and buffer addition on duodenal flow of trans- $\mathrm{C}_{18: 1}$ fatty acids and milk fat production in dairy cows. J. Dairy Sci. 80:2104-2114.

McKinnon, J. J., D. A. Christensen, and B. Laarveld. 1990. The influence of bicarbonate buffers on milk production and acid-base balance in lactating dairy cows. Can. J. Anim. Sci. 70:875-886.

Miller, R. W., R. W. Hemken, D. R. Waldo, M. Okamoto, and L. A. Moore. 1965. Effect of feeding buffers to dairy cows fed a highconcentrate, low-roughage ration. J. Dairy Sci. 48:1455.

Mooney, C. S., and M. S. Allen. 2007. Effect of dietary strong ions on chewing activity and milk production in lactating dairy cows. J. Dairy Sci. 90:5610.

NRC. 2001. Nutrient Requirements of Dairy Cattle. 7th rev. ed. Natl. Acad. Press, Washington, DC.

Oba, M., and M. S. Allen. 1999. Evaluation of the importance of digestibility of neutral detergent fiber from forage: Effects on dry matter intake and milk yield of dairy cows. J. Dairy Sci. 82:589 596.

Perfield, J. W. II, A. L. Lock, A. Sæbø, J. M. Griinari, D. A. Dwyer, and D. E. Bauman. 2007. Trans-9, cis-11 conjugated linoleic acid (CLA) reduces milk fat synthesis in lactating dairy cows. J. Dairy Sci. 90:2211-2218.

Piperova, L. S., J. Sampugna, B. B. Teter, K. F. Kalscheur, M. P. Yurawecz, K. Ku, K. M. Morehouse, and R. A. Erdman. 2002. Duodenal and milk trans octadecenoic acid and conjugated linoleic acid (CLA) isomers indicate that postabsorptive synthesis is the predominant source of cis 9 containing CLA in lactating dairy cows. J. Nutr. 132:1235-1241.

Roche, J. R., S. Petch, and J. K. Kay. 2005. Manipulating the dietary cation-anion difference via drenching to early-lactation dairy cows grazing pasture. J. Dairy Sci. 88:264-276.

Rogers, J. A., C. L. Davis, and J. H. Clark. 1982. Alteration of rumen fermentation, milk fat synthesis and nutrient utilization with minerals salts in dairy cows. J. Dairy Sci. 65:577-586.

Rogers, J. A., L. D. Muller, C. L. Davis, W. Chalupa, D. S. Kronfield, L. F. Krocher, and K. R. Cummings. 1985a. Response of dairy cows to sodium bicarbonate and limestone in early lactation. J. Dairy Sci. 68:646-660.

Rogers, J. A., L. D. Muller, T. J. Snyder, and T. L. Maddox. 1985b. Milk production, nutrient digestion, and rate of digesta passage in dairy cows fed long or chopped alfalfa hay supplemented with sodium bicarbonate. J. Dairy Sci. 68:868-880.

Saebø, A., P. C. Saebø, J. M. Griinari, and K. J. Shingfield. 2005. Effect of abomasal infusions of geometric isomers of 10,12 conjugated linoleic acid on milk fat synthesis in dairy cows. Lipids 40:823-832.

Sanchez, W. K., and D. K. Beede. 1996. Is there an optimal dietary cation-anion difference for lactation diets? Anim. Feed Sci. Technol. 59:3-12.

Sanchez, W. K., D. K. Beede, and J. A. Cornell. 1997. Dietary mixtures of sodium bicarbonate, sodium chloride, and potassium chloride: Effects on lactational performance, acid-base status, and mineral metabolism of Holstein cows. J. Dairy Sci. 80:1207-1216.

Schneider, P. L., D. K. Beede, and C. J. Wilcox. 1986. Responses of lactating cows to dietary sodium source and quantity and potassium quantity during heat stress. J. Dairy Sci. 69:99-110.
Snyder, T. J., J. A. Rogers, and L. D. Muller. 1983. Effects of $1.2 \%$ sodium bicarbonate with two ratios of corn silage: grain on milk production, rumen fermentation and nutrient digestion by lactating dairy cows. J. Dairy Sci. 66:1290-1297.

St-Pierre, N. R. 2001. Invited review: Integrating quantitative findings from multiple studies using mixed model methodology. J. Dairy Sci. 84:741-755.

Stanley, R. W., N. Kanjanipibul, K. Morita, and S. M. Ishizaki. 1972. Effect of feeding buffered concentrate rations on the performance and metabolism of lactating dairy cattle in a sub-tropical environment. J. Dairy Sci. 55:959-963.

Stokes, M. R., L. L. Vandemark, and L. S. Bull. 1986. Effects of sodium bicarbonate, magnesium oxide, and a commercial buffer mixture in early lactation cows fed hay crop silage. J. Dairy Sci. 69:1595-1603.

Teh, T. H., R. W. Hemken, and R. J. Harmon. 1985. Dietary magnesium oxide interactions with sodium bicarbonate on cows in early lactation. J. Dairy Sci. 68:881.

Tucker, W. B., G. A. Harrison, and R. W. Hemken. 1988a. Influence of dietary cation-anion balance on milk, blood, urine, and rumen fluid in lactating dairy cattle. J. Dairy Sci. 71:346-354.

Tucker, W. B., I. S. Shin, J. F. Hogue, M. Aslam, G. D. Adams, M. T. Van Koevering, R. K. Vernon, and K. R. Cummings. 1994. Natural sodium sesquicarbonate fed for an entire lactation: Influence on performance and acid-base status of dairy cows. J. Dairy Sci. 77:3111-3117.

Tucker, W. B., Z. Xin, and R. W. Hemken. 1988b. Influence of dietary calcium chloride on adaptive changes in acid-base status and mineral metabolism in lactating dairy cows fed a diet high in sodium bicarbonate. J. Dairy Sci. 71:1587-1597.

Van Horn, H. H., B. Harris Jr., M. J. Taylor, K. C. Bachman, and C. J. Wilcox. 1984. By-product feeds for lactating dairy cows: Effects of cottonseed hulls, sunflower hulls, corrugated paper, peanut hulls, sugarcane bagasse and whole cottonseed with additives of fat, sodium bicarbonate, and Aspergillus oryzae product on milk production. J. Dairy Sci. 67:2922-2938.

West, J. W., C. E. Coppock, D. H. Nave, J. M. Labore, L. W. Greene, and T. W. Odom. 1987. Effects of potassium carbonate and sodium bicarbonate on rumen function in lactating Holstein cows. J. Dairy Sci. 70:81-90.

West, J. W., C. E. Coppock, D. H. Nave, and G. T. Schelling. 1986. Effects of potassium buffers on feed intake in lactating dairy cows and on rumen fermentation in vivo and in vitro. J. Dairy Sci. 69:124-134.

West, J. W., K. D. Haydon, B. G. Mullinix, and T. G. Sandifer. 1992. Dietary cation anion balance and cation source effects on production and acid-base status of heat-stressed cows. J. Dairy Sci. $75: 2776-2786$.

West, J. W., B. G. Mullinix, and T. G. Sandifer. 1991. Changing dietary electrolyte balance for dairy cows in cool and hot environments. J. Dairy Sci. 74:1662-1674

Wildman, C. D., J. W. West, and J. K. Bernard. 2007a. Effects of dietary cation-anion difference and potassium to sodium ratio on lactating dairy cows in hot weather. J. Dairy Sci. 90:970-977.

Wildman, C. D., J. W. West, and J. K. Bernard. 2007b. Effect of dietary cation-anion difference and dietary crude protein on milk yield, acid-base chemistry, and rumen fermentation. J. Dairy Sci. 90:4693-4700.

Wildman, C. D., J. W. West, and J. K. Bernard. 2007c. Effect of dietary cation-anion difference and dietary crude protein on performance of lactating dairy cows during hot weather. J. Dairy Sci. 90:1842-1850. 